\title{
Synthesis, Characterization, Thermochromism, and Photochromism of Aromatic Aldehyde Hydrazone Derivatives
}

\author{
ShaoPing Zhu, Yuan Chen, Jun Sun, YuTing Yang, and ChuanJun Yue \\ School of Science, Changzhou Institute of Technology, 1 Wushan Street, Changzhou, Jiangsu 213002, China \\ Correspondence should be addressed to ShaoPing Zhu; zhushaoping18@163.com
}

Received 26 April 2016; Revised 5 July 2016; Accepted 27 July 2016

Academic Editor: Davut Avci

Copyright (c) 2016 ShaoPing Zhu et al. This is an open access article distributed under the Creative Commons Attribution License, which permits unrestricted use, distribution, and reproduction in any medium, provided the original work is properly cited.

\begin{abstract}
The Schiff bases N-(5-phenylthiazole-2-yl)-2-hydroxylnaphthaldehydehydrazone (1), N-(4'-chloro-5-phenylthiazole-2-yl)-2hydroxylnaphthaldehydehydrazone (2), and N-(4'-nitro-5-phenylthiazole-2-yl)-2-hydroxylnaphthaldehydehydrazone (3) were synthesized. These compounds were characterized by using IR, ${ }^{1} \mathrm{HNMR},{ }^{13} \mathrm{CNMR}$, and MS. The photochromism of the compounds was investigated by IR and UV-visible spectrometry which is time variable under irradiation of $254 \mathrm{~nm}$ UV light. The thermochromism of the compounds was studied using temperature-variable IR, UV-visible spectrometry, TG, and differential scanning calorimetry (DSC). The results suggested that compound $\mathbf{2}$ showed thermochromism properties and compounds $\mathbf{2}$ and 3 displayed photochromism properties. The relationship between the substituents species and photochromic or thermochromic properties of these compounds was revealed as well.
\end{abstract}

\section{Introduction}

Of the many Schiff bases, o-hydroxylnaphthaldehydehydrazone had been found to be unique classes of Schiff bases with reversible thermochromism, photochromism, and other interesting properties. It was known that Schiff bases experience reversible phototransformations or thermal transformations between two forms, in particular, between enolimine form and keto-amine form [1]. The tautomerism of the Schiff bases played an important role in their photochromic and thermochromic characteristics $[2,3]$. When heated or receiving ultraviolet radiation, the hydrogen atom of the $\mathrm{O}-\mathrm{H}$ or $\mathrm{N}-\mathrm{H}$ transferred and attached to the $\mathrm{N}$ atom of $\mathrm{C}=\mathrm{N}$ or $\mathrm{O}$ atom of $\mathrm{C}=\mathrm{O}$ (Scheme 2) leading to $\pi-\pi$ charge transfer. The tautomerization between enol-imine and ketoamine achieved by proton migrating thermally or through irradiation induction, so orthohydroxyl played an important part on both thermochromism and photochromism of such Schiff bases $[4,5]$. A link between molecular planar structures and thermochromism or photochromism has been proposed $[6,7]$. Planarity of the molecule made it possible for the proton to transfer with small energy requirement $[8,9]$. Substituents on the aromatic ring might also have an influence on the proton transfer $[10,11]$.
In this study, three Schiff bases (1-3) were synthesized (Scheme 1). The thermochromism or photochromism of the compounds were also studied. The results suggested that although the compounds (1-3) were all o-hydroxyl Schiff bases, compound $\mathbf{1}$ showed no thermochromism or photochromism, so o-hydroxyl was not the only factor work for the thermochromic or photochromic properties; the substituent species on the phenyl ring had great effect on such properties.

\section{Experimental}

2.1. Materials and Methods. All the required chemicals were purchased from Sinopharm Chemical Reagent Co., Ltd, and were used without further purification. Melting points of the compounds were determined on SGWX-4 digital micromelting point apparatus. FT-IR spectra were recorded on a Thermo Scientific System 2000 FT-IR spectrometer. NMR spectra were recorded on AVANCE III NMR spectrometer in deuterated DMSO with TMS as an internal standard at $300 \mathrm{MHz}$ for ${ }^{1} \mathrm{H}$ and for $75 \mathrm{MHz}$ for ${ }^{13} \mathrm{C}$. LC mass spectra were recorded on SHIMADZU, LCMS-2020 MS instrument with resolution $>40000$ FWHM. The UV-visible spectra 


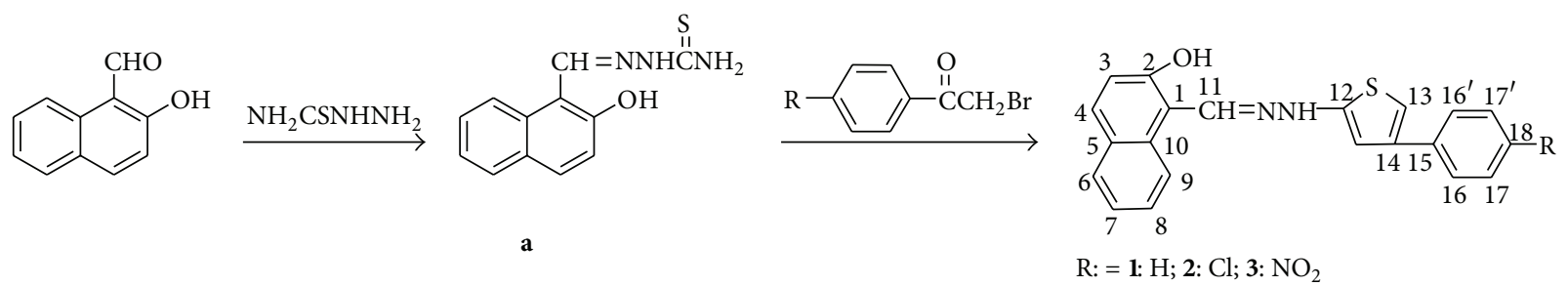

SCHEME 1

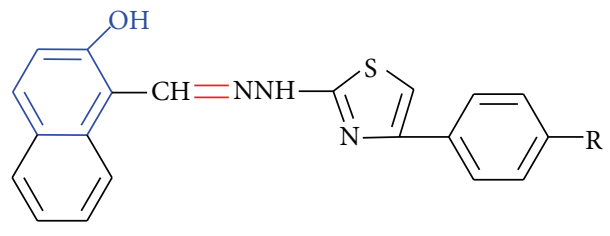

Enol-imine

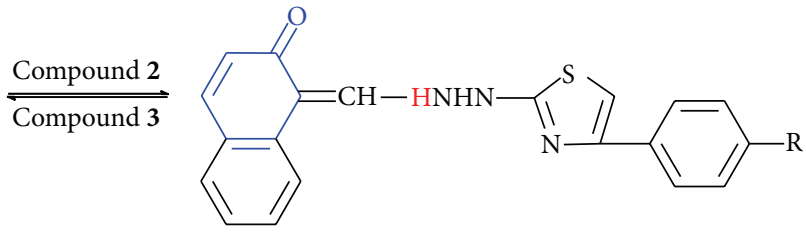

Keto-amine

SCHEME 2: Tautomerism of aromatic aldehyde hydrazones.

were measured using a TU-1901 ultraviolet spectrophotometer. DSC analysis was performed by a DZ3335 differential scanning calorimeter (DSC) and TG analysis was detected by a STA449-F5TAQ600 analyzer. ZF-6 UV-light analyzer $(254 \mathrm{~nm}, 365 \mathrm{~nm})$ was used as the radiation source.

2.2. General Procedure for the Synthesis of Aromatic Aldehyde Hydrazone Derivatives. To a $250 \mathrm{~mL}$ three-neck round flask containing $182 \mathrm{mg}(2 \mathrm{mmol})$ of aminothiourea in $25 \mathrm{~mL}$ ethanol (80\%), $344 \mathrm{mg}$ ( $2 \mathrm{mmol}$ ) of 2-hydroxy-1-naphthaldehyde was dissolved in $20 \mathrm{~mL}$ absolute ethanol. Then $2 \mathrm{~mL}$ of glacial acetic acid was added. The resulting mixture was magnetically stirred and refluxed for 4 hours. The solution was poured into a beaker and laid in ice baths for 2 hours to precipitate. The solid was recrystallized from ethanol-DMF (volume ratio, $1: 1$ ) and dried at $40^{\circ} \mathrm{C} ; 461 \mathrm{mg}$ golden yellow solid (yield: 94\%) was obtained. The solid was 2-hydroxy-1-naphthaldehydethiosemicarbazone (a).

$245 \mathrm{mg}(1 \mathrm{mmol})$ of compound a was dissolved in $25 \mathrm{~mL}$ absolute ethanol, and $199 \mathrm{mg}(1 \mathrm{mmol}) \alpha$-bromoacetophenone or $244 \mathrm{mg}$ ( $1 \mathrm{mmol}$ ) 2-bromo-4'-chloroacetophenone or $245 \mathrm{mg}$ ( $1 \mathrm{mmol}) \alpha$-bromo-4-nitroacetophenone in $10 \mathrm{~mL}$ ethanol was added, respectively.

The reaction mixture was refluxed for 30 minutes. The mixture became clear in a moment. Five minutes later, a great deal of solid appeared. Solid (compound 1, 2, or 3) was obtained after suction filtration and recrystallized with ethanol-DMF (volume ratio, $1: 1$ ).

\subsection{Spectral Data}

N-(5-Phenylthiazole-2-yl)-2-hydroxylnaphthaldehydehydrazone (1). $250 \mathrm{mg}$, yield 72.6\%, bright yellow solid, m.p. 200-202 ${ }^{\circ}$ C. IR $\left(\mathrm{KBr}, v / \mathrm{cm}^{-1}\right): 3320\left(v_{\mathrm{O}-\mathrm{H}}\right), 3111\left(\nu_{\mathrm{N}-\mathrm{H}}\right), 3073$, 2971 (stretching vibration of $\mathrm{Ar}-\mathrm{H}$ and thiazole-H, resp.), $1619\left(v_{\mathrm{C}=\mathrm{N}}\right), 1611,1581,1491,1480$ (Ar; thiazole ring), 1409, 1349 (rocking vibration of Ar-H and thiazole-H, resp.), 1319 $\left(\nu_{\mathrm{C}-\mathrm{OH}}\right), 756,733$ (out-of-plane ring bending vibration of
Ar-H and thiazole-H, resp.); ${ }^{1} \mathrm{H}$ NMR (DMSO-d6, $300 \mathrm{MHz}$, ppm) $\delta: 12.29$ (s, 1H, OH), 11.02 (s, 1H, N-H), 8.97 (s, 1H, $\mathrm{H}-\mathrm{C}=\mathrm{N}), 8.74-8.71(\mathrm{~d}, 1 \mathrm{H}$, thiazole-H), 7.89-7.86 (t, $4 \mathrm{H}$, naphthalene- $\mathrm{H}), 7.62-7.57(\mathrm{~m}, 1 \mathrm{H}$, naphthalene- $\mathrm{H}), 7.46-7.43$ (d, $1 \mathrm{H}$, naphthalene- $\mathrm{H}), 7.41-7.40(\mathrm{~d}, 2 \mathrm{H}$, benzene- $\mathrm{H})$, 7.37-7.30 ( $\mathrm{m}, 2 \mathrm{H}$, benzene-H), 7.25-7.22 (d, 1H, benzene-H). ${ }^{13} \mathrm{C}-\mathrm{NMR}$ (75 MHz, DMSO-d6, ppm): $\delta 168.2\left(\mathrm{C}_{12}\right), 156.9$ $\left(\mathrm{C}_{2}\right), 150.5\left(\mathrm{C}_{11}\right), 141.8\left(\mathrm{C}_{14}\right), 134.8\left(\mathrm{C}_{13}\right), 132.4\left(\mathrm{C}_{15}\right), 131.5$ $\left(\mathrm{C}_{18}\right), 129.3\left(\mathrm{C}_{17}, \mathrm{C}_{17^{\prime}}\right), 129.1\left(\mathrm{C}_{16}, \mathrm{C}_{16^{\prime}}\right), 128.6\left(\mathrm{C}_{1}\right), 128.2(\mathrm{~d}, \mathrm{~J}$ $\left.=86.3, \mathrm{C}_{5}, \mathrm{C}_{10}\right), 126.1\left(\mathrm{C}_{4}\right), 123.9\left(\mathrm{C}_{3}\right), 123.4\left(\mathrm{C}_{6}\right), 118.7\left(\mathrm{C}_{9}\right)$, $110.6\left(\mathrm{C}_{7}\right), 103.61\left(\mathrm{C}_{8}\right)$; ESIMS calculated for $\mathrm{C}_{20} \mathrm{H}_{15} \mathrm{~N}_{3} \mathrm{OS}$ : 345.42 , found $m / z=346.10[\mathrm{M}+\mathrm{H}]^{+}, m / z=368.10[\mathrm{M}+\mathrm{Na}]^{+}$, $\mathrm{m} / z=344.05[\mathrm{M}-\mathrm{H}]^{+}$.

$N$-(4'-Choro-5-phenylthiazole-2-yl)-2-hydroxylnaphthaldehydehydrazone (2). $277 \mathrm{mg}$, yield 73\%, gray purple crystal, m.p. $302-304^{\circ} \mathrm{C}$. IR (KBr, $\left.\nu / \mathrm{cm}^{-1}\right): 3333\left(\nu_{\mathrm{O}-\mathrm{H}}\right), 3112\left(\nu_{\mathrm{N}-\mathrm{H}}\right)$, 2921, 2851 (stretching vibration of Ar-H and thiazole-H, resp.), $1629\left(v_{\mathrm{C}=\mathrm{N}}\right), 1600,1580,1560,1490$ (Ar; thiazole ring), 1469,1419 (rocking vibration of Ar-H and thiazole-H, resp.), $1399\left(v_{\mathrm{C}-\mathrm{OH}}\right), 779,739$ (out-of-plane ring bending vibration of Ar-H and thiazole-H, resp.). ${ }^{1} \mathrm{H}$ NMR (DMSO-d6, $300 \mathrm{MHz}$, ppm) $\delta: 12.27$ (s, $1 \mathrm{H}, \mathrm{OH}), 10.94$ (s, $1 \mathrm{H}, \mathrm{N}-\mathrm{H}), 8.96$ (s, $1 \mathrm{H}$, $\mathrm{H}-\mathrm{C}=\mathrm{N}), 8.77-8.74(\mathrm{~s}, 1 \mathrm{H}$, thiazole-H), 7.92-9.86 (t, $4 \mathrm{H}$, naphthalene- $\mathrm{H}), 7.62-7.57(\mathrm{t}, 1 \mathrm{H}$, naphthalene- $\mathrm{H}), 7.50-7.48$ (d, $1 \mathrm{H}$, naphthalene-H), 7.44-7.42 (d, 1H, benzene-H), 7.407.37 (d, 2H, benzene-H), 7.25-7.22 (d, 1H, benzene-H), 706 $\left(v_{\mathrm{C}-\mathrm{Cl}}\right) .{ }^{13} \mathrm{C}-\mathrm{NMR}(75 \mathrm{MHz}, \mathrm{DMSO}-\mathrm{d} 6, \mathrm{ppm}): \delta 173.0\left(\mathrm{C}_{18}\right)$, 161.6 $\left(\mathrm{C}_{12}\right), 154.6\left(\mathrm{C}_{2}\right), 146.5\left(\mathrm{C}_{11}\right), 138.6\left(\mathrm{C}_{14}\right), 137.3\left(\mathrm{C}_{13}\right)$, $137.1\left(\mathrm{C}_{17}, \mathrm{C}_{17^{\prime}}\right), 136.3\left(\mathrm{C}_{16}, \mathrm{C}_{16^{\prime}}\right), 134.0\left(\mathrm{C}_{15}\right), 133.8\left(\mathrm{C}_{1}\right), 133.4$ $\left(\mathrm{C}_{5}\right) 132.9\left(\mathrm{C}_{10}\right), 132.5\left(\mathrm{C}_{4}\right), 128.6\left(\mathrm{C}_{3}\right), 128.1\left(\mathrm{C}_{6}\right), 123.5\left(\mathrm{C}_{9}\right)$, $115.3\left(\mathrm{C}_{7}\right), 109.1\left(\mathrm{C}_{8}\right)$. ESIMS calculated for $\mathrm{C}_{20} \mathrm{H}_{14} \mathrm{~N}_{3} \mathrm{OSCl}$ 379.86 , found $m / z=380.00[\mathrm{M}+\mathrm{H}]^{+}, m / z=378.00[\mathrm{M}-\mathrm{H}]^{+}$, $m / z=402.05[\mathrm{M}+\mathrm{Na}]^{+}$.

$N$-(4'-Nitro-5-phenylthiazole-2-yl)-2-hydroxylnaphthaldehydehydrazone (3). $306 \mathrm{mg}$, yield 78.4\%, shallow orange crystal, m.p. $257-259^{\circ} \mathrm{C} . \mathrm{IR}\left(\mathrm{KBr}, \nu / \mathrm{cm}^{-1}\right): 3309\left(\nu_{\mathrm{O}-\mathrm{H}}\right), 3118\left(\nu_{\mathrm{N}-\mathrm{H}}\right)$, 
2921, 2851 (Ar-H, thiazole-H), $1619\left(\nu_{\mathrm{C}=\mathrm{N}}\right), 1601,1580,1499$, 1469 (Ar; thiazole ring), 1521, 1330 (stretching vibration of the nitro group), 1439, 1419 (rocking vibration of $\mathrm{Ar}-\mathrm{H}$ or thiazole-H), $1371\left(\nu_{\mathrm{C}-\mathrm{OH}}\right), 777,746$ (out-of-plane ring bending vibration of Ar-H and thiazole-H, resp.). ${ }^{1} \mathrm{H}$ NMR (DMSO-d6, $300 \mathrm{MHz}, \mathrm{ppm}$ ) $\delta: 12.36$ (s, 1H, OH), 10.89 (s, $1 \mathrm{H}, \mathrm{N}-\mathrm{H}), 8.96(\mathrm{~s}, 1 \mathrm{H}, \mathrm{H}-\mathrm{C}=\mathrm{N}), 8.82-8.80$ (d, $1 \mathrm{H}$, thiazole$\mathrm{H}), 8.32-8.29$ (d, 2H, naphthalene-H), 8.16-8.13 (d, 2H, naphthalene-H), 7.89-7.86 (d, 2H, naphthalene-H), 7.77 (s, $1 \mathrm{H}$, benzene- $\mathrm{H}), 7.62-7.57(\mathrm{t}, 1 \mathrm{H}$, benzene- $\mathrm{H}), 7.42-7.37(\mathrm{t}$, $1 \mathrm{H}$, benzene-H), 7.25-7.22 (d, $1 \mathrm{H}$, benzene- $\mathrm{H}) .{ }^{13} \mathrm{C}-\mathrm{NMR}$ (75 MHz, DMSO-d6, ppm) $\delta: 168.6\left(\mathrm{C}_{18}\right), 156.9\left(\mathrm{C}_{12}\right), 149.1$ $\left(\mathrm{C}_{2}\right), 146.7\left(\mathrm{C}_{11}\right), 141.9\left(\mathrm{C}_{14}\right), 141.0\left(\mathrm{C}_{13}\right), 132.5\left(\mathrm{C}_{17}, \mathrm{C}_{17^{\prime}}\right)$, $131.5\left(\mathrm{C}_{16}, \mathrm{C}_{16^{\prime}}\right), 129.3\left(\mathrm{C}_{15}\right), 128.7\left(\mathrm{C}_{1}\right), 128.2\left(\mathrm{C}_{5}\right), 126.9$ $\left(\mathrm{C}_{10}\right), 124.6\left(\mathrm{C}_{4}\right), 123.9\left(\mathrm{C}_{3}\right), 123.7\left(\mathrm{C}_{6}\right), 118.6\left(\mathrm{C}_{9}\right), 110.6$ $\left(\mathrm{C}_{7}\right)$, $108.6\left(\mathrm{C}_{8}\right)$; ESIMS calculated for $\mathrm{C}_{20} \mathrm{H}_{14} \mathrm{~N}_{4} \mathrm{O}_{3} \mathrm{~S} 390.42$, found $m / z=391.10[\mathrm{M}+\mathrm{H}]^{+}, m / z=388.95[\mathrm{M}-\mathrm{H}]^{+}, m / z=$ $413.25[\mathrm{M}-\mathrm{Na}]^{+}$.

\section{Results and Discussion}

\subsection{Thermochromism}

3.1.1. IR Spectroscopic and TG Studies. The color of compound 2 changed from gray purple to brown after being heated to $229^{\circ} \mathrm{C}$ and restored the original color after cooling. To investigate the thermochromism of the compounds thoroughly, $\mathrm{KBr}$ tablets of $\mathbf{1 - 3}$ were heated to certain temperatures on the electric hot plate; then the IR spectra were measured promptly. The IR spectra of $\mathbf{2}$ were shown in Figure 1(a). Compound 2 had the characteristic stretching band of hydroxyl group $(\mathrm{O}-\mathrm{H})$ at $3333 \mathrm{~cm}^{-1}$. When compound 2 was heated to $140^{\circ} \mathrm{C}$, the absorption peak intensity of hydroxyl group absorption peak decreased partly the result of a conversion of the hydroxyl group to the carbonyl group (Scheme 2). When the temperature reached $200^{\circ} \mathrm{C}$, the band almost disappeared. When compound 2 was heated to $60^{\circ} \mathrm{C}$, a small absorption peak appeared at $1763 \mathrm{~cm}^{-1}$. This was due to the stretching vibration of the carbonyl of the keto-amine, which was produced from enol-imine of compound $\mathbf{2}$ on heating [12-14].

In fingerprint region (Figure 1(b)), small new absorption peaks appeared at $756 \mathrm{~cm}^{-1}$ and $695 \mathrm{~cm}^{-1}$, while the peak at $652 \mathrm{~cm}^{-1}$ diminished. All of these changes were ascribed to the bending vibration of the $\mathrm{C}-\mathrm{H}$ bond of the losing aromaticity ring of the keto-amine [12-14].

Figure 2 was the TG curve of compound 2. The TG curve suggested that there was a loss weight in the beginning of the test. The loss weight had relations to the loss of the crystal water in the molecule. Because the band of crystal water in IR spectra overlapped that of hydroxyl group, the reduction of the intensity at $3333 \mathrm{~cm}^{-1}$ in Figure 1(a) was about more than the loss of crystal water. Similar intensity changes could be observed in Figure 7. By photoirradiation, the absorption peak intensity at $3333 \mathrm{~cm}^{-1}$ of unheated compound 2 became smaller gradually without the loss of crystal water. So the intensity decreased partly because of the tautomerism and Figure 4 confirmed the discussion as

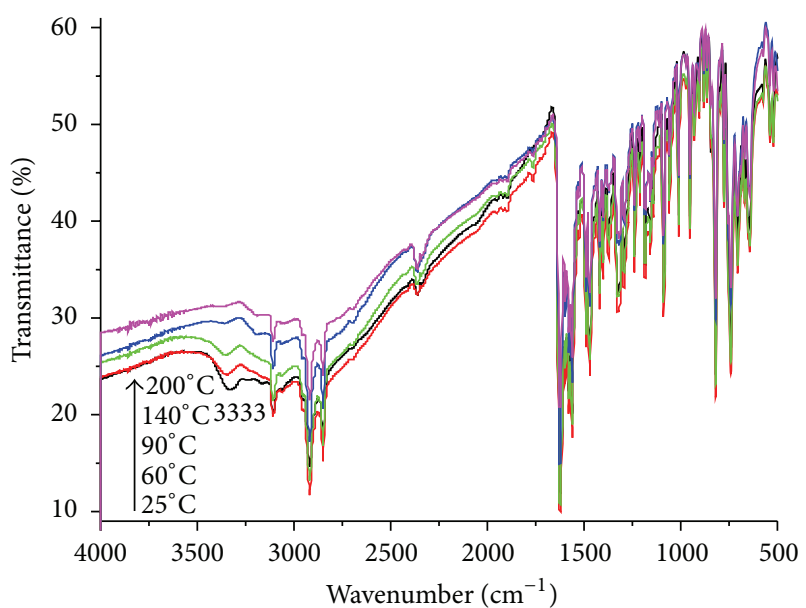

(a)

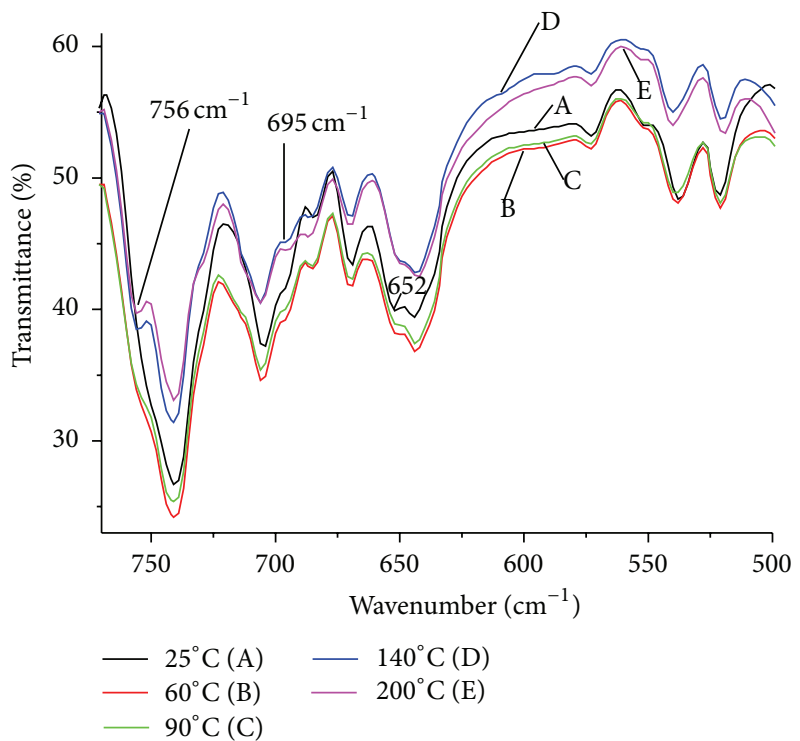

(b)

FIGURE 1: The IR spectra of compound 2 on heating in the whole spectra range investigated (a) and in the narrowed range (b).

well. The band at $3333 \mathrm{~cm}^{-1}$ in Figure 1(a) almost disappeared when temperature rose to $200^{\circ} \mathrm{C}$. It was still the result of the loss of the crystal water and tautomerism. All the crystal water lost at this moment and maybe most enol-imine form of compound 2 changed to enol-amine form.

When the temperature rose to $337^{\circ} \mathrm{C}$, compound 2 lost weight again because it started to decompose.

3.1.2. The DSC Measurement. The DSC curves of compounds 1-3 were shown in Figure 3. Compound 2 exhibited three endothermic peaks at $229^{\circ} \mathrm{C}, 303^{\circ} \mathrm{C}$, and $343^{\circ} \mathrm{C}$, respectively. The first endothermic peak at $229^{\circ} \mathrm{C}$ corresponded to color change temperature; the second and the third endothermic peak corresponded to the melting point and decomposition temperature, respectively. The results further confirmed that compound 2 showed thermochromism. The melting point 


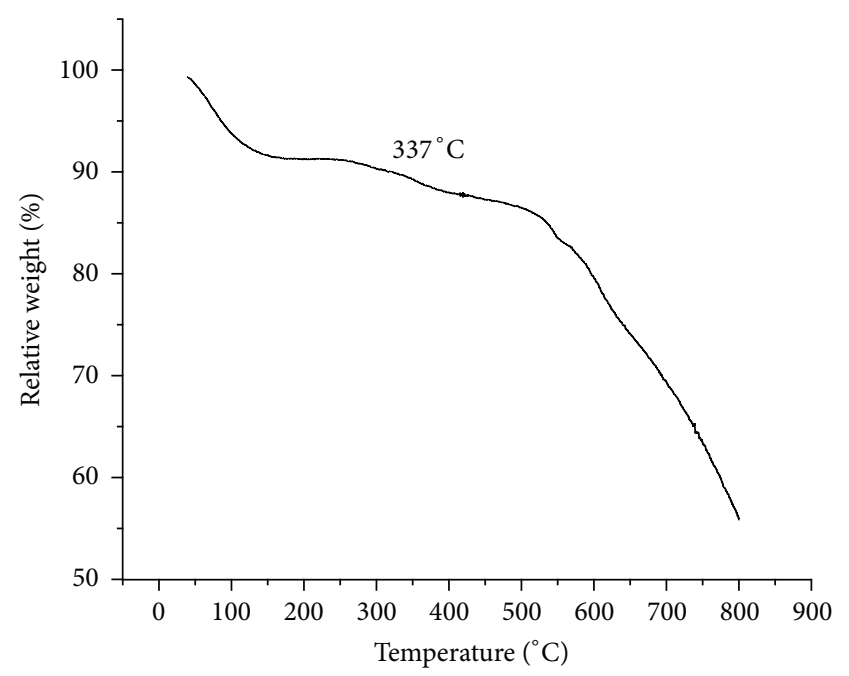

FIgURE 2: The TG curve of compound 2.

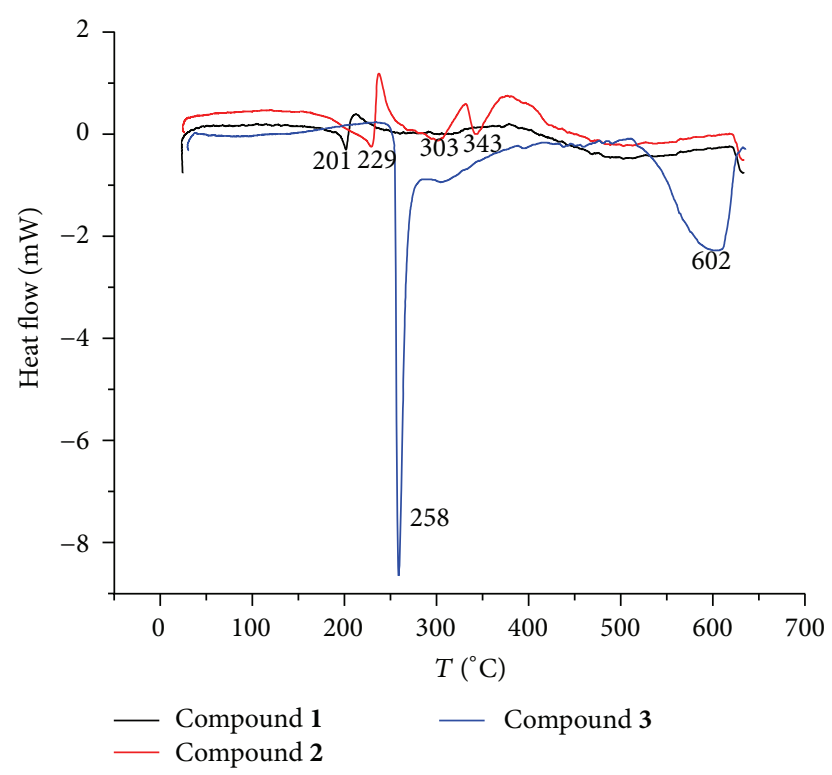

FIGURE 3: The DSC curves for compounds 1-3.

peaks for compounds 1 and 3 were $201^{\circ} \mathrm{C}$ and $258^{\circ} \mathrm{C}$, respectively. There was another endothermic peak at $602^{\circ} \mathrm{C}$ for compound $\mathbf{3}$ which was a decomposition peak.

3.1.3. UV-Visible Spectroscopic Studies. The UV-visible spectra of orthohydroxylated Schiff bases existing mainly as enolimine structure indicated the presence of bands at $<400 \mathrm{~nm}$. However, the compounds existing as either keto-amine or mixture of enol-imine/keto-amine forms showed a new band at $>400 \mathrm{~nm}$ [15]. Photochromism or thermochromism was the phenomenon of chromatic change due to the reversible photoisomerization or thermomerization between the two tautomers which showed different absorption bands and absorbance changes of the bands [16-20].

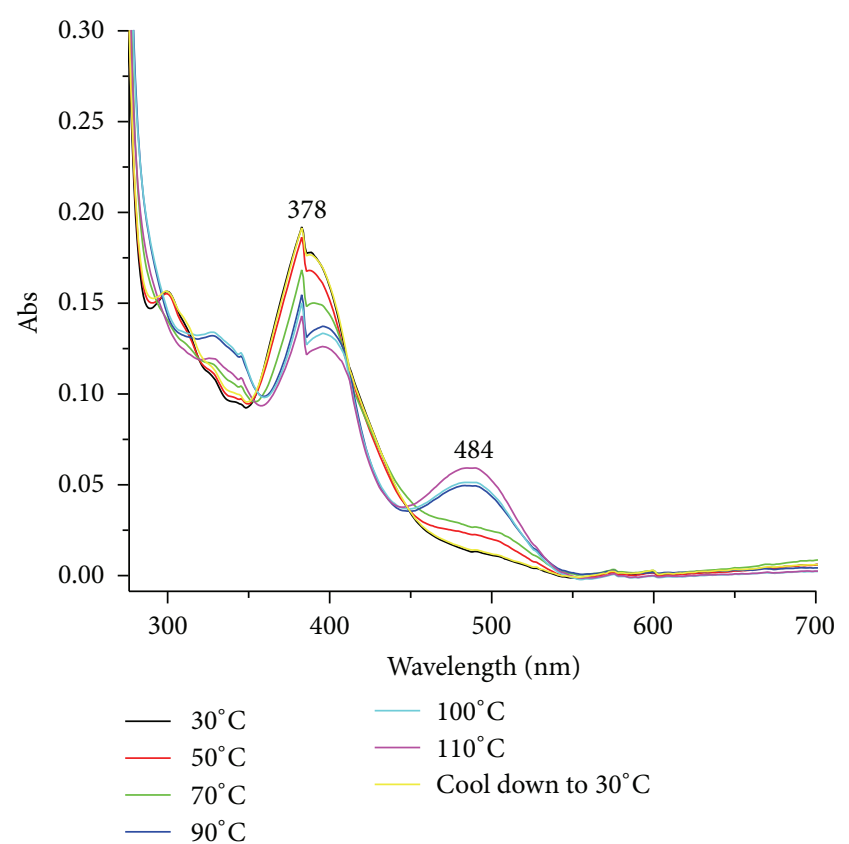

FIgURE 4: The UV-vis spectra of compound 2 on heating.

Figure 4 showed the UV-visible absorption spectra change of compound 2 on heating. The yellow DMF solution of compound 2 (concentration: $1.0 \times 10^{-5} \mathrm{~mol} / \mathrm{L}$, path length: $1 \mathrm{~cm}$ ) transformed to light orange. The intensity of the absorption peak at $378 \mathrm{~nm}$ decreased, and a new band appeared at $484 \mathrm{~nm}$. The absorption peak intensity of the new band became greater with temperature rising. The heated solution was left to rest for enough time to cool down to room temperature, and the color of the solution came back to yellow. UV-visible absorption spectra were tested again. The result was showed in Figure 4 as well. The absorption curve of the cooled compound $\mathbf{2}$ was compared with that of the unheated compound $\mathbf{2}$ and they agreed well. These indicated that compound $\mathbf{2}$ had reversible thermochromism.

\subsection{Photochromism}

3.2.1. UV-Visible Spectroscopic Studies. Figures 5 and 6 showed the UV-visible absorption spectra changes of compounds $\mathbf{2}$ and $\mathbf{3}$ upon irradiation of $254 \mathrm{~nm}$ UV light, respectively. The yellow DMF solution of compound $\mathbf{2}$ (concentration: $1.0 \times 10^{-5} \mathrm{~mol} / \mathrm{L}$, path length: $1 \mathrm{~cm}$ ) transformed to pale orange under the UV light. The intensity of the absorption peak at $378 \mathrm{~nm}$ decreased and a new band appeared at $480 \mathrm{~nm}$ which kept increasing as the exposure time went on.

The orange red DMF solution of compound 3 transformed to orange yellow under the UV light (concentration: $1.0 \times 10^{-5} \mathrm{~mol} / \mathrm{L}$, path length: $1 \mathrm{~cm}$ ). Furthermore, the intensity of the absorption peak at $469 \mathrm{~nm}$ became smaller, while the absorption peak at $377 \mathrm{~nm}$ increased gradually. The changes of the absorption peaks of compounds $\mathbf{2}$ and $\mathbf{3}$ supported that the two compounds underwent tautomerism. Because the ratio of keto-amine form of compound 2 increased under UV irradiation, the absorbance of the peak 


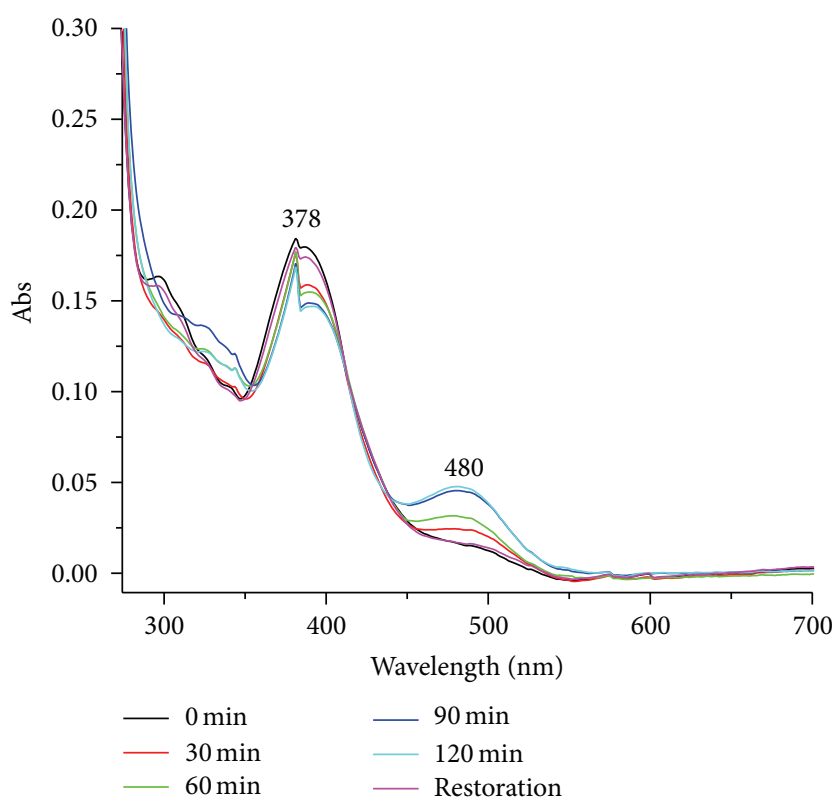

Figure 5: The UV-vis spectra of compound 2 after a period of exposure to UV light.

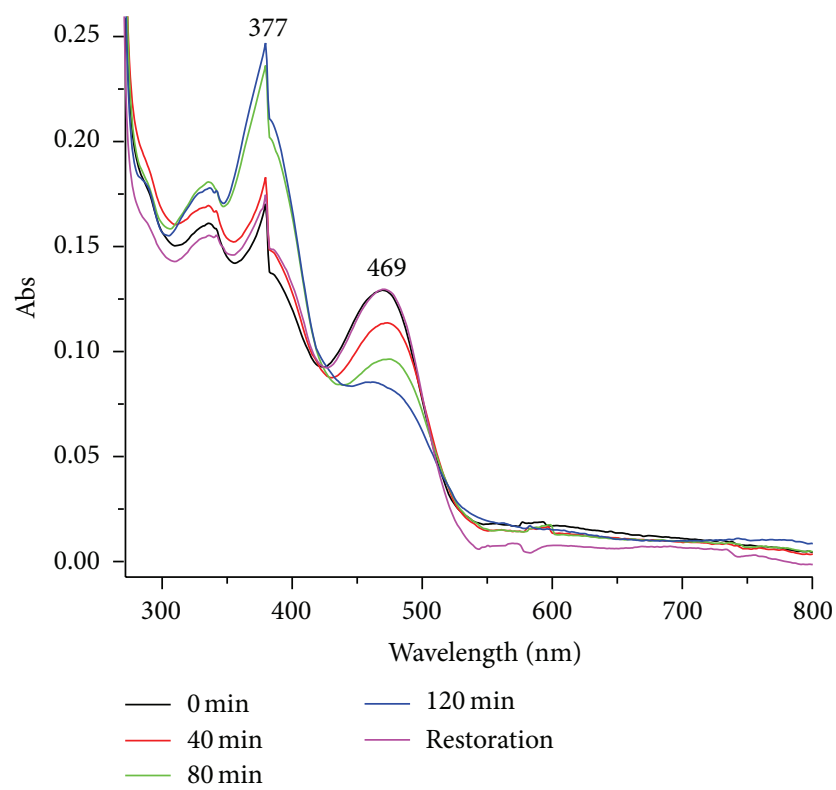

Figure 6: The UV-vis spectra of compound 3 after a period of exposure to UV light.

at greater than $400 \mathrm{~nm}$ increased. For the same reason, the ratio of the enol-imine form of compound 3 increased while the keto-amine decreased after irradiation of UV light [21].

The UV light was removed after the solutions exposure to it for two hours. The solutions were let to stand for 24 hours and the UV-visible spectra of the compounds were detected again. The spectra of the restored compounds 2 and 3 were also showed in Figures 5 and 6, respectively. The absorption curves were of close resemblance to the spectra of the compounds without irradiation with UV light.

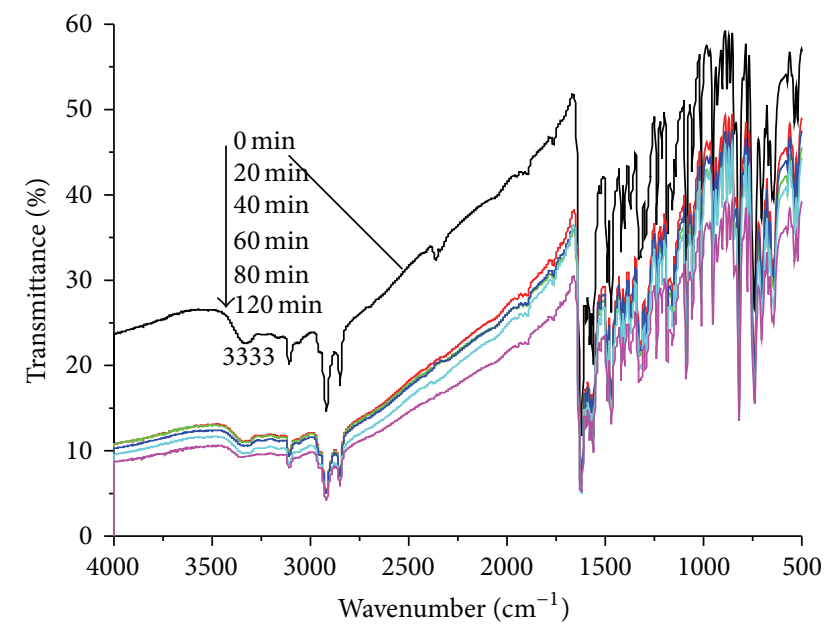

FIGURE 7: The IR spectra of compound 2 after a period of exposure to UV light.

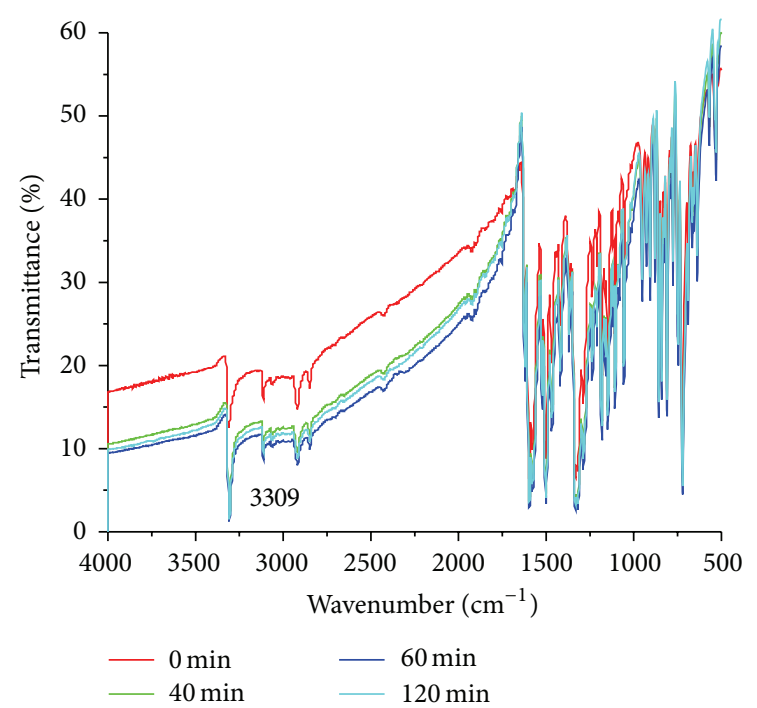

FIGURE 8: The IR spectra of compound 3 after a period of exposure to UV light.

Meanwhile, the color of the solutions was nearly back, so both of compounds $\mathbf{2}$ and $\mathbf{3}$ were reversible photochromic.

3.2.2. IR Spectroscopic Studies. The IR spectra of $\mathbf{2}$ and $\mathbf{3}$ were taken on each exposure time by the $254 \mathrm{~nm}$ UV light. The time-variable behavior of the IR spectra of compounds 2 and 3 exposure to UV light was shown in Figures 7 and 8 , respectively. In Figure 7, The hydroxyl group $(\mathrm{O}-\mathrm{H})$ stretching band was observed at $3333 \mathrm{~cm}^{-1}$ for compound 2 . Upon irradiation with ultraviolet (UV) light, the intensity of the stretching band decreased. It was confirmed that the enolimine form of compound $\mathbf{2}$ changed partially to keto-amine, while in Figure 8 the hydroxyl group $(\mathrm{O}-\mathrm{H})$ stretching band of compound 3 at $3309 \mathrm{~cm}^{-1}$ became greater which confirmed that part of the keto-amine turned to enol-imine form when exposed to UV light. 


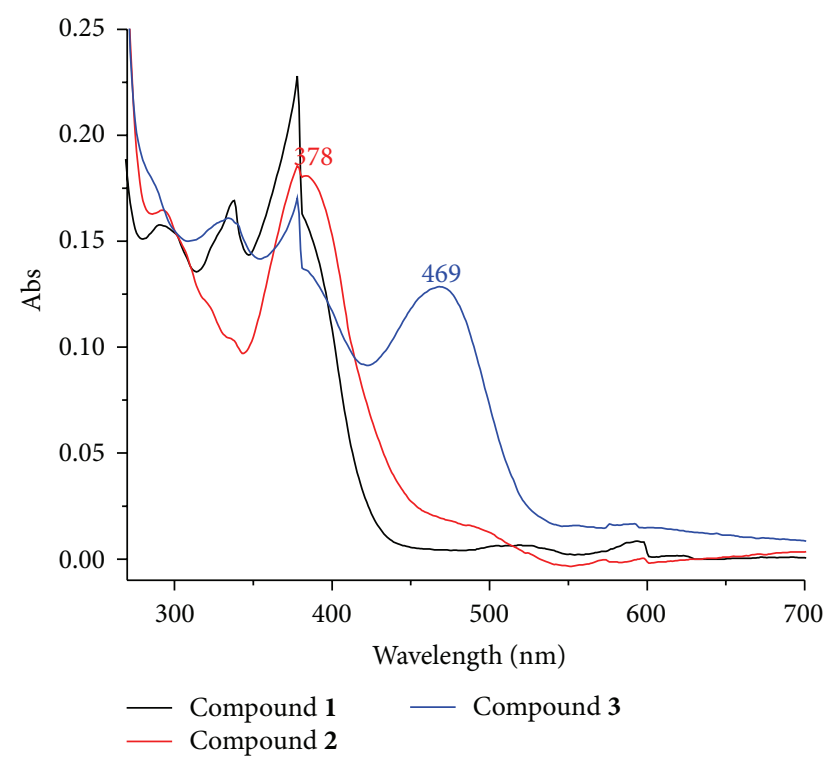

Figure 9: The UV-vis spectra of compounds 1, 2, and 3.

3.3. The Effect of Substituents on Thermochromism or Photochromism. Based on what had been discussed above, compounds $\mathbf{2}$ and $\mathbf{3}$ showed thermochromism and compound $\mathbf{2}$ exhibited photochromism, both phenomena being associated with an intramolecular proton transfer which led to the tautomerism between the enol-imine and the keto-amine [7]. But compound 1 had no similar properties. Orthohydroxyl was essential for the intramolecular proton transfer. Compounds 1, 2, and 3 were all orthohydroxyl Schiff bases and their structures were similar except for the difference in the substituents on the phenyl groups, so the substituent species effected the proton transfer as well.

Figures 9 and 10 were the UV-vis spectra of compounds 1-3 and those of the compounds exposure to the UV light for two hours, respectively. The results showed that compound 1 existed as enol-imine form and changed little after irradiation. Compound 2 existed as enol-imine form and transformed to keto-amine form, and the conversion $\left(\alpha=\left(A \%-A_{0} \%\right) / A_{0} \% ; \alpha\right.$ was conversion; $A_{0} \%$ and $A \%$ were the absorbance of a compound before and after irradiation by UV light) was nearly $11 \%$ at $378 \mathrm{~nm}$. As for compound $\mathbf{3}$, the conversion of keto-amine to enol-imine was about $36 \%$ at $469 \mathrm{~nm}$.

Hammett parameters (paranitro: +0.778 , para-Cl: +0.227 , $\mathrm{H}: 0.0$ ) were important basis for judging substituents effects on the reaction of benzene ring. For example, the alkalinity of p-nitroaniline was weaker than aniline due to the charge population on $\mathrm{N}$ atom being less and proton capacity weakened since the nitro group was a strong electron-withdrawing group. But p-nitroaniline and p-nitrophenylhydrazine were only alkaline which accept proton rather than lose proton.

But here it was evident that the molecule of compound 3 was a system containing several aryl rings and amino group was not isolated. If the proton on $\mathrm{N}$ atom could transfer, a double bond formed between the $\mathrm{N}$ atom and the neighboring $\mathrm{C}$ atom. Meanwhile, the unsaturated cyclic ketone

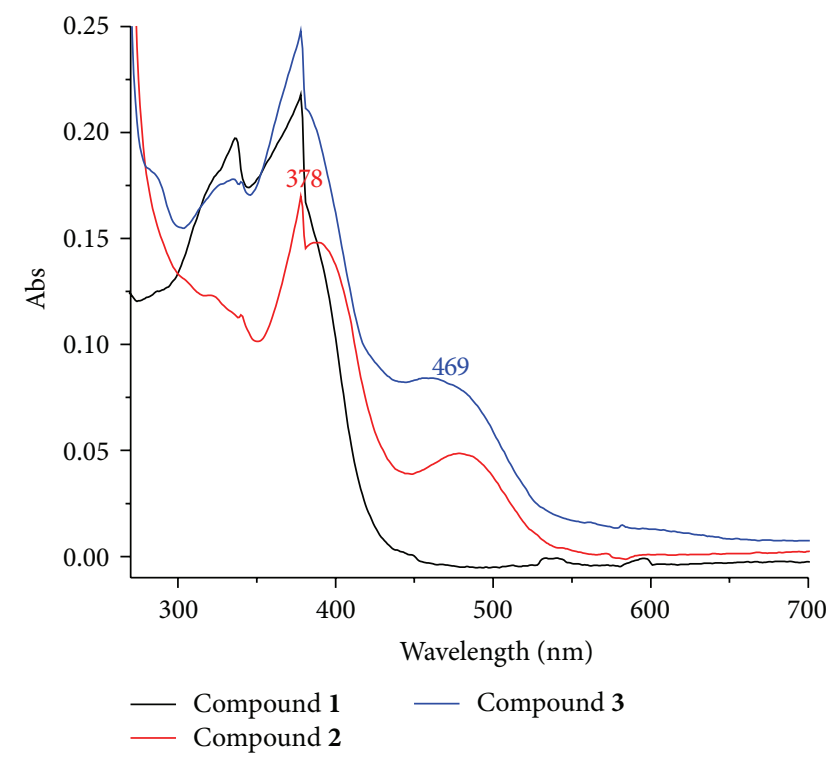

FIGURE 10: The UV-vis spectra of compounds 1, 2, and 3 exposure to UV light for $120 \mathrm{~min}$.

changed to a much more stable benzene ring. Furthermore, the benzene ring and $\mathrm{C}=\mathrm{N}$ formed conjugated system and the whole molecule became more stable. So the proton transfer could take place [20, 22-29].

The paranitro group made less charge population on $\mathrm{N}$ atom of amino group due to inductive effect and the shared electron pair deviate from $\mathrm{H}$ atom and turn to $\mathrm{N}$ atom which is advantageous to the hydrogen proton on $\mathrm{N}$ atom going away.

The substituent of compound $\mathbf{2}$ was a chlorine atom which was also an electron- withdrawing group. The compound tended to turn enol-imine into keto-amine form. Whatever the direction of the tautomerism, intramolecular proton in compounds $\mathbf{2}$ and $\mathbf{3}$ transferred more readily than compound 1.

\section{Conclusion}

Investigations of three naphthaldehyde hydrazone derivatives were conducted. It was found that not all of the o-hydroxyl Schiff bases exhibited thermochromism and photochromism. Compounds 1, 2, and 3 had similar structures, but the substituted species on phenyl ring were different. Compound $\mathbf{2}$ showed thermochromism and compounds $\mathbf{2}$ and $\mathbf{3}$ showed photochromism. As for compound 1, it showed no such properties. So the substituted species was a very important prerequisite in these properties. Results of UV-visible and IR analyses showed that compound $\mathbf{2}$ existed as enol-imine form. Heated to a certain temperature or exposed to UV light for a period of time, it partially transformed to keto-amine. Part of the keto-amine tautomer of compound 3 changed to enol-imine tautomer upon UV-light irradiation. Of these three compounds, the electron-withdrawing substituents on the benzene ring seemed to help the tautomerism. 


\section{Additional Points}

All additional information pertaining to characterization of the complexes using ESI-MS technique (Figures S1, S1, and S1"; S4, S4', and S4"; S7, S7', and S7"), ' H NMR (Figures S2, S5, and S8), and ${ }^{13} \mathrm{C} \mathrm{NMR}$ (Figures S3, S3'; S6; and S9) is given in Supplementary Material available online at http://dx.doi.org/ $10.1155 / 2016 / 8460462$.

\section{Competing Interests}

The authors declare that they have no competing interests.

\section{References}

[1] M. Ziółek and I. Sobczak, "Photochromism and hydrolysis of aromatic Schiff base N,N'-bis(salicylidene) -p-phenylenediamine (BSP) studied in heterogeneous environments," Journal of Inclusion Phenomena and Macrocyclic Chemistry, vol. 63, no. 34, pp. 211-218, 2009.

[2] D. Guha, A. Mandal, A. Koll, A. Filarowski, and S. Mukherjee, "Proton transfer reaction of a new orthohydroxy Schiff base in protic solvents at room temperature," Spectrochimica Acta Part A: Molecular and Biomolecular Spectroscopy, vol. 56, no. 14, pp. 2669-2677, 2000.

[3] M. Z. Zgierski and A. Grabowska, "Theoretical approach to photochromism of aromatic Schiff bases: a minimal chromophore salicylidene methylamine," The Journal of Chemical Physics, vol. 113, no. 18, pp. 7845-7852, 2000.

[4] S. Mintova, V. De Waele, M. Hölzl et al., "Photochemistry of 2-(2I-Hydroxyphenyl)benzothiazole encapsulated in nanosized zeolites," The Journal of Physical Chemistry A, vol.108, no. 48, pp. 10640-10648, 2004.

[5] K. Amimoto and T. Kawato, "Photochromism of organic compounds in the crystal state," Journal of Photochemistry and Photobiology C: Photochemistry Reviews, vol. 6, no. 4, pp. 207226, 2005.

[6] M. E. Kletskii, A. A. Millov, A. V. Metelitsa, and M. I. Knyazhansky, "Role of structural flexibility in the fluorescence and photochromism of salicylideneaniline: the general scheme of the phototransformations," Journal of Photochemistry and Photobiology A: Chemistry, vol. 110, no. 3, pp. 267-270, 1997.

[7] A. Elmali, M. Kabak, E. Kavlakoglu, Y. Elerman, and T. N. Durlu, "Tautomeric properties, conformations and structure of N-(2-hydroxy-5- chlorophenyl) salicylaldimine," Journal of Molecular Structure, vol. 510, no. 1-3, pp. 207-214, 1999.

[8] N. Hoshino, T. Inabe, T. Mitani, and Y. Maruyama, "Structure and optical properties of a thermochromic Schiff base. Thermally induced intramolecular proton transfer in the $\mathrm{N}, \mathrm{N}^{\prime}$ bis(salicylidene)-p-phenylenediamine crystals," Bulletin of the Chemical Society of Japan, vol. 61, no. 12, pp. 4207-4214, 1988.

[9] Q. Wang, W. Qiu, J. Wu, and M. Zhang, "Schiff base compounds derived from (R)-3-phenyl-2-phthalimidopropionic acid: photochromism, solvatochromism, and fluorescence," Journal of Structural Chemistry, vol. 24, no. 1, pp. 295-301, 2013.

[10] R. Jin and J. Zhang, "Substituent effects in the tuning of excited-state intramolecular proton transfer and optical properties of the derivatives of 2-(2-hydroxyphenyl)-5-phenyl-1,3,4oxadiazole," Theoretical Chemistry Accounts, vol. 124, no. 5-6, pp. 331-338, 2009.
[11] L. Kong, X. Ju, Y. Zhang, J. Zhao, and J. Xu, "Substituent effect of a donor unit on electrochemical and opto-electronic properties of ambipolar benzotriazole-based polymers," Iranian Polymer Journal, vol. 25, no. 5, pp. 443-454, 2016.

[12] L. J. Bellamy, The Infrared Spectra of Complex Molecules, Chapman and Hall, London, UK, 1980.

[13] J. P. Charles, Aldrich Library of FT-IR Spectra, Aldrich Chemical Co, Milwaukee, Wis, USA, 1985.

[14] L. V. Daimay, B. C. Norman, G. F. William et al., The Handbook of Infrared and Roman Characteristic Frequencies of Organic Molecules, Academic Press, San Diego, Calif, USA, 1990.

[15] H. Ünver, M. Yıldız, A. Kiraz, and Ö. Özgen, "Spectroscopic studies and crystal structure of (Z)-6-[(2- hydroxyphenylamino)methylene]-2-methoxycyclohexa-2,4-dienone," Journal of Chemical Crystallography, vol. 39, no. 1, pp. 17-23, 2009.

[16] H. Shoji, D. Kitagawa, and S. Kobatake, "Systematic study on the thermal cycloreversion reactivity of diarylethenes with alkoxy and alkyl groups at the reactive carbons," Research on Chemical Intermediates, vol. 39, no. 1, pp. 279-289, 2013.

[17] M. Yildiz, "Synthesis and spectroscopic studies of some new polyether ligands of the Schiff base type," Spectroscopy Letters, vol. 37, no. 4, pp. 367-381, 2004.

[18] H. Ünver, "Synthesis and spectroscopic studies in some new Schiff bases," Spectroscopy Letters, vol. 34, no. 6, pp. 783-791, 2001.

[19] R. Herzfeld and P. Nagy, "Roles of the acidity and basicity of the solvent in the solvent effect observed in the absorption spectra of certain types of Schiff bases," Spectroscopy Letters, vol. 32, no. 1, pp. 57-71, 1999.

[20] H. Ünver, D. M. Zengin, and K. Güven, "Intramolecular hydrogen bonding and tautomerism in 1-[N-(4-bromophenyl)]aminomethylidene-2(1H) naphthalenone," Journal of Chemical Crystallography, vol. 30, no. 5, pp. 359-364, 2000.

[21] H. Ünver, M. Yıldız, D. M. Zengin, S. Özbey, and E. Kendi, "Intramolecular hydrogen bonding and tautomerism in N-(3pyridil)-2-oxo-1-naphthylidenemethylamine," Journal of Chemical Crystallography, vol. 31, no. 4, pp. 211-216, 2001.

[22] T. Hökelek, M. Işiklan, and Z. Kiliç, "Crystal structure of 1-[N-(6-methyl-2-pyridyl)aminomethylidene] 2(1H)-naphthalenone," Analytical Sciences, vol. 16, no. 1, pp. 99-100, 2000.

[23] J. M. Ortiz-Sánchez, R. Gelabert, M. Moreno, and J. M. Lluch, "Electronic-structure and quantum dynamical study of the photochromism of the aromatic Schiff base salicylideneaniline," The Journal of Chemical Physics, vol. 129, no. 21, Article ID 214308, 2008.

[24] Y. Ito, K. Amimoto, and T. Kawato, "Prototropic tautomerism and solid-state photochromism of N-phenyl-2-aminotropones," Dyes and Pigments, vol. 89, no. 3, pp. 319-323, 2011.

[25] V. I. Minkin, A. V. Tsukanov, A. D. Dubonosov, and V. A. Bren, "Tautomeric Schiff bases: iono-, solvato-, thermo- and photochromism," Journal of Molecular Structure, vol. 998, no. 1-3, pp. 179-191, 2011.

[26] E. Hadjoudis and I. M. Mavridis, "Photochromism and thermochromism of Schiff bases in the solid state: structural aspects," Chemical Society Reviews, vol. 33, no. 9, pp. 579-588, 2004.

[27] E. Hadjoudis, K. Yannakopoulou, S. D. Chatziefthimiou, A. Paulidou, and I. M. Mavridis, "Supramolecular control of photochromism in a $\beta$-cyclodextrin/Schiff base system," Journal of Photochemistry and Photobiology A: Chemistry, vol. 217, no. 2-3, pp. 293-298, 2011. 
[28] H. Ünver, E. Kendi, K. Güven, and T. N. Durlu, "Synthesis, spectroscopic studies, crystal structure and conformation analysis of N-(2-fluoro-3-methoxy)-salicylaldimine," Zeitschrift fur Naturforschung-Section B Journal of Chemical Sciences, vol. 57, no. 6, pp. 685-690, 2002.

[29] Y. Elerman, M. Kabak, A. Elmali, and I. Svoboda, "1-[N-(4methyl-2-pyridyl)aminomethyl-idene]-2(1H)-naphthalenone," Acta Crystallographica Section C: Crystal Structure Communications, vol. 54, no. 1, pp. 128-130, 1998. 

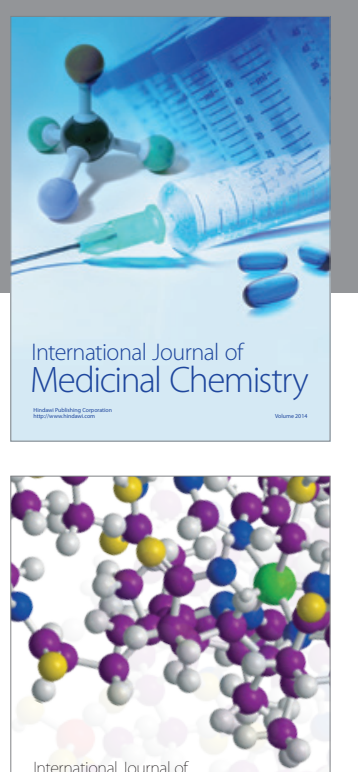

Carbohydrate Chemistry

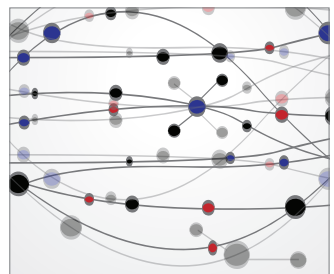

The Scientific World Journal
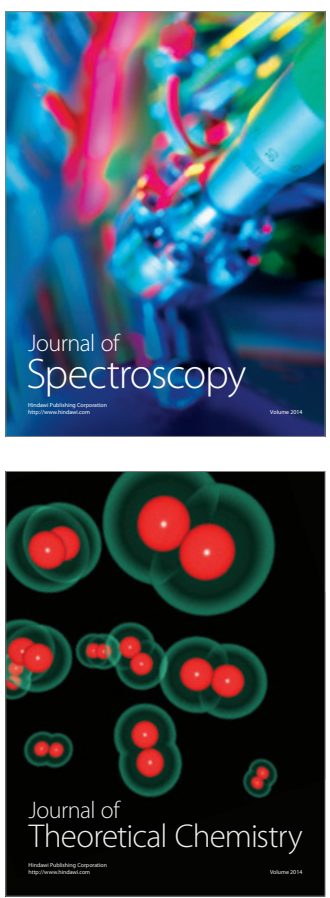
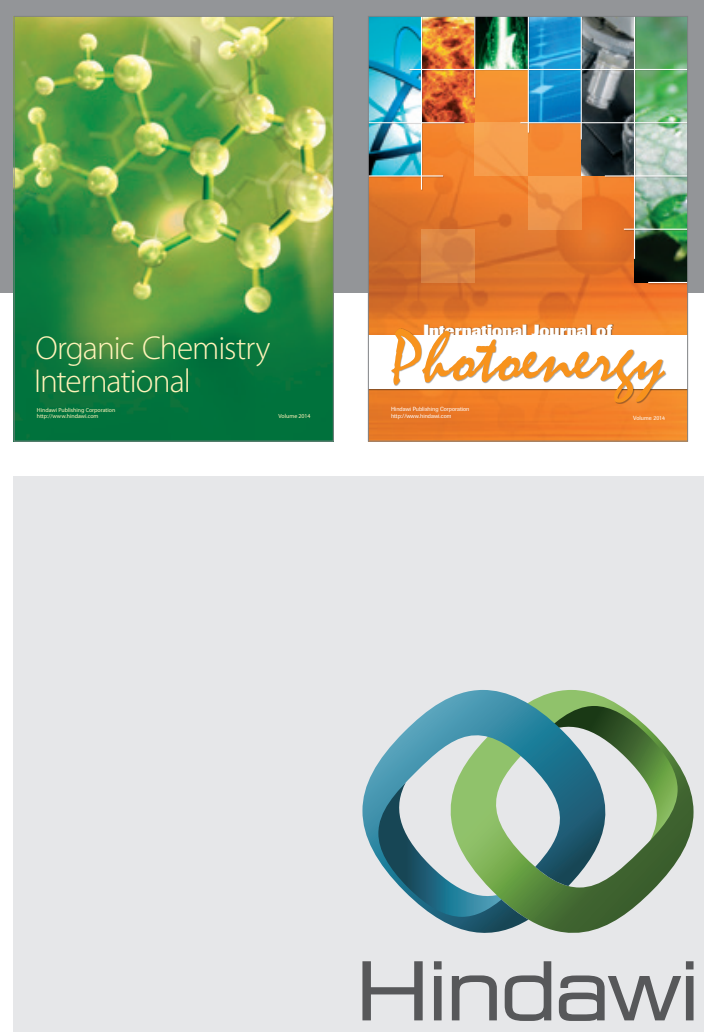

Submit your manuscripts at

http://www.hindawi.com

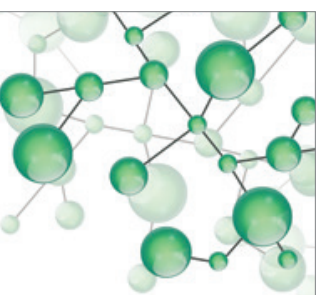

International Journal of

Inorganic Chemistry

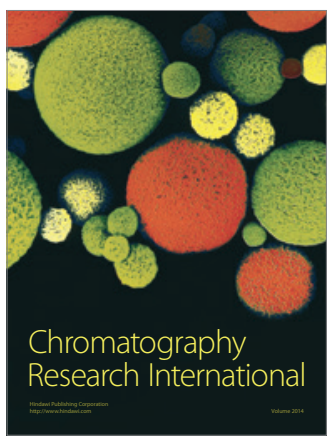

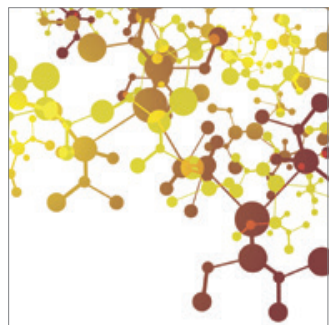

Applied Chemistry
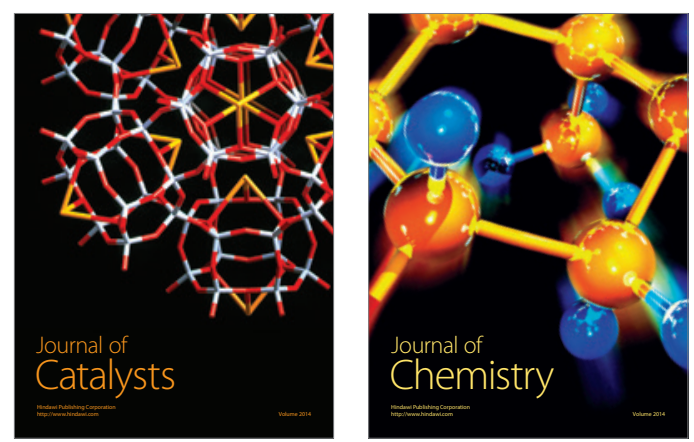
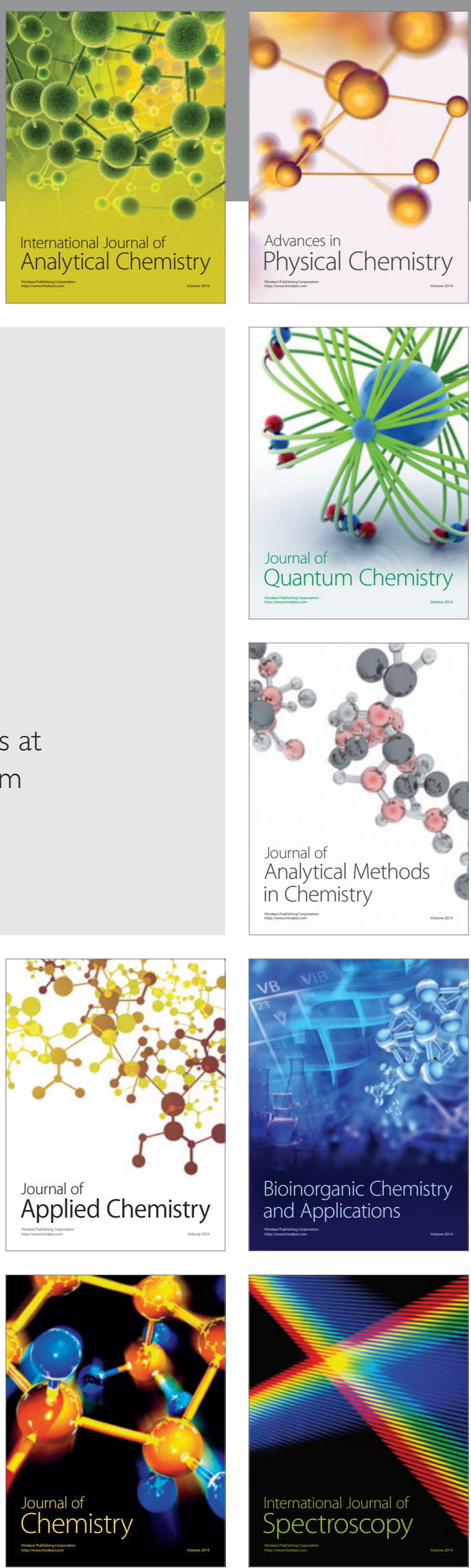